\title{
Total kandungan antioksidan ekstrak etanol buah beringin (Ficus benjamina Linn.)
}

\author{
Anderson Arnold Aloanis ${ }^{* a}$, Marlina Karundeng ${ }^{a}$ \\ a Kimia, FMIPA, Universitas Negeri Manado, Tondano, 95618, Indonesia
}

\begin{tabular}{l} 
I N F O A R T I K E L \\
\hline Diterima 2 November 2018 \\
Disetujui 24 April 2019 \\
\hline Key word: \\
Figs \\
antioxidant \\
ethanol \\
\hline Kata kunci: \\
Buah beringin \\
antioksidan \\
etanol \\
\hline
\end{tabular}

\begin{abstract}
A B STRACT
Nowadays the need for antioxidants is increasing. Advances in technology and sciences encourage an increase in the number of free radicals and oxidizing compounds. This study aims to measure the total antioxidant content of the ethanolic extract of beringin (Ficus benjamina Linn.) fruit. Measurement of total antioxidant capacity begins with extraction by maceration. The freshly picked banyan fruit is macerated using 95\% ethanol for $3 \times 24$ hours. Maceration is carried out at room temperature and kept away from sunlight. The macerated filtrate is then evaporated to get a thick ethanol extract. The ethanol extract was then measured for its antioxidant ability using phosphomolybdenum assay. Measurement using UV-Vis spectrophotometer. The measurement results showed the antioxidant activity of ethanol extract is $43.73 \mathrm{mg} / \mathrm{gram} A A E$.
\end{abstract}

*e-mail:

marlinakarundeng@unima.ac.id

*Telp:

08114320980

\begin{abstract}
ABSTRAK
Dewasa ini kebutuhan akan antioksidan meningkat. Kemajuan teknologi dan ilmu pengetahuan alam mendorong peningkatan jumlah senyawa-senyawa radikal bebas dan oksidator. Penetlitian ini bertujuan untuk mengkur kandungan total antioksidan ekstrak etanol buah beringin (Ficus benjamina Linn.). Pengukuran kandungan total antioksidan dimulai dengan ekstraksi dengan cara maserasi. Buah beringin yang baru dipetik dimaserasi dengan menggunakan etanol 95\% selama $3 \times 24$ jam. Maserasi dilakukan pada suhu ruang dan dijauhkan dari sinar matahari. Filtrat hasil maserasi kemudian dievaporasi hingga mendapatkan ekstrak kental etanol. Ekstrak etanol kemudian diukur kemampuan antioksidannya menggunakan uji fosfomolybdenum. Pengukuran menggunakan spektrovotometer UV-Vis. Hasil pengukuran menunjukkan aktivitas antioksidan ekstrak etanol sebesar $43.73 \mathrm{mg} / \mathrm{gram}$ AAE.
\end{abstract}

\section{Pendahuluan}

Antioksidan dibagi menjadi menjadi antioksidan enzimatik dan antioksidan non enzimatik [1]. Antioksidan non enzimatik berupa kofaktor, mineral, vitamin, karotenoid dan senyawa fenolik. Antioksidan memiliki peran yang luas dalam kehidupan manusia. Senyawa prooksidan dan antioksidan telah dimiliki oleh tubuh manusia. Dapat disadari bahwa mayoritas penyakit disebabkan oleh tidak seimbangnya prooksidan dan antioksidan dalam metabolisme tubuh manusia [2]. Keseimbangan tersebut dapat terganggu dengan pengaruh lingkungan dan gaya hidup yang buruk misalnya: asap kendaraan, pemanasan global, sinar UV dan kebiasaan merokok [3].

Keseimbangan yang terganggu harus diimbangi dengan suplai antioksidan dari luar tubuh manusia. Buah-buahan merupakan salah satu sumber antioksidan yang paling mudah diperoleh. Buah-buahan yang berwarna seperti 
anggur menunjukkan kadar fenolik yang tinggi. Buah Ficus Benjamina merupakan buah yang dapat dimakan namun buah ini tidak dibudidayakan sebagai sumber nutrisi. Beberapa buah genus ficus telah diteliti dan terbukti kemampuan antioksidannya [4-12]. Beberapa buah dari genus ficus atau yang biasa disebut fig telah diisolasi senyawa-senyawa fenolik seperti flavonoid dan terpenoid $[13,14]$

\section{Bahan dan Metode}

Bahan yang digunakan dalam penilitian ini adalah asam sulfat (Merck), Natrium Hidrogen Fosfat (Merck), Amonium molibdat (Sigma Aldrich), Akuades, Asam askorbat. Alat yang digunakan adalah tabung reaksi, pipet (tetes, ukur, mikro), labu takar, gelas ukur, erlenmeyer, waterbath, spektrofotometer UV-Vis (Lambda 25).

Total kandungan antioksidan diukur dengan uji fosfomolybdenum menggunakan metode Aliyu (2013) dengan sedikit modifikasi[15]. Ekstrak sebanyak 0,3 mL dicampurkan dengan $3 \mathrm{~mL}$ larutan reagen (asam sulfat 0,6 M, $28 \mathrm{mM}$ natrium hydrogen fosfat dan ammonium molibdat $4 \mathrm{mM}$ ) ke dalam tabung reaksi. Tabung yang mengandung larutan reaksi dan ekstrak diinkubasi pada suhu $95^{\circ} \mathrm{C}$ selama 90 menit. Kemudian, absorbansi larutan diukur pada 695 $\mathrm{nm}$ menggunakan spektrofotometer UV-VIS terhadap blanko setelah pendinginan sampai suhu kamar. Akuades $(0,3 \mathrm{~mL})$ di tempat ekstrak digunakan sebagai blanko. Total kandungan antioksidan dinyatakan sebagai jumlah gram setara Asam askorbat. Kurva kalibrasi dibuat dengan mencampurkan Asam askorbat (62.5, 31.25, dan $15.625 \mu \mathrm{g} / \mathrm{mL}$ ) dengan akuades.

\section{Hasil dan Pembahasan}

Buah beringin berwarna merah yang baru dipetik dan masih segar diambil di Kabupaten Minahasa. Buah ini dihaluskan, ditimbang dan dimaserasi dengan pelarut etanol 95\%. Maserasi dilakukan selama 24 jam pada suhu ruangan dan diulang sebanyak tiga kali. Filtrat hasil maserasi digabung dan kemudian dievaporasi pada suhu $40^{\circ} \mathrm{C}$ hingga terbentuk ekstrak kental etanol. Evaporasi pada suhu yang terlalu tinggi dapat meningkatkan resiko rusaknya struktur senyawa hingga terbentuknya senyawa artefak. Hal ini juga dapat menggangu aktivitas dari senyawasenyawa yang terdapat dalam buah Beringin ( $F$. Benjamina Linn.).

$$
\mathrm{H}_{3}\left(\mathrm{P}\left(\mathrm{Mo}_{3} \mathrm{O}_{10}\right)_{4}\right)+12 \mathrm{H}^{+} \rightarrow \mathrm{H}_{15}\left(\mathrm{P}\left(\mathrm{Mo}_{3} \mathrm{O}_{10}\right)_{4}\right)
$$

Pengukuran antioksidan menggunakan metode fosfomolibdenum merupakan pengukuran terhadap reduksi kompleks fosfat$\mathrm{Mo}(\mathrm{VI})$ menjadi kompleks fosfat-Mo(V) pada $\mathrm{pH}$ asam [15]. kompleks fosfat-Mo(VI) yang tidak berwarna akan berubah menjadi kompleks fosfat-Mo(V) yang berwarna biru. Pada gambar 1 diperlihatkan bagaimana reaksi pelepasan ion $\mathrm{H}^{+}$dari asam askorbat yang akan digunakan untuk mereduksi kompleks fosfatMo (IV). Reaksi reduksi dengan ion $\mathrm{H}^{+}$dari asam askorbat maupun dari sampel digambarkan pada persamaan reaksi (1). Semakin pekat warna biru yang terbentuk menandakan semakin banyak kompleks fosfat$\mathrm{Mo}(\mathrm{V})$ yang terbentuk yang juga berarti semakin baik kemampuan dari sampel sebagai antioksidan.

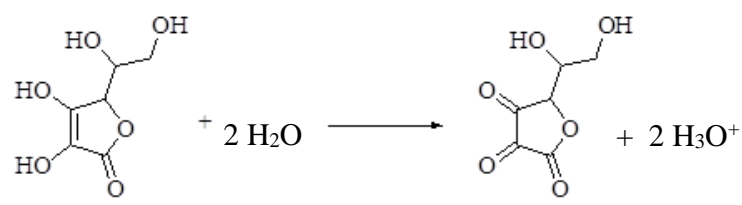

Gambar 1. Reaksi pelepasan $\mathrm{H}^{+}$dari Asam askorbat

Tabel 1. Total kandungan antioksidan

\begin{tabular}{lllll}
\hline \multirow{1}{*}{$\begin{array}{c}\text { Asam } \\
\text { askorbat }\end{array}$} & \multicolumn{3}{c}{$\begin{array}{c}\text { Ekstrak etanol } \\
(1000 \mu \mathrm{g} / \mathrm{mL})\end{array}$} & $\begin{array}{l}\text { Rata- } \\
\text { rata } \pm \\
\end{array}$ \\
\cline { 2 - 4 } & $\mathrm{R}{ }_{1}$ & $\mathrm{R}_{2}$ & $\mathrm{R}_{3}$ & $\begin{array}{l}\mathrm{SD} \\
(\mathrm{n}=3)\end{array}$ \\
\hline $\mathrm{y}=0.0545 \mathrm{x}$ & 52.379 & 43.774 & 47.022 & 47.73 \\
-0.5737 & & & & \pm \\
$\left(\mathrm{R}^{2}=0.998\right)$ & & & & 4.3456 \\
& & & & $\mathrm{mg} / \mathrm{gr}$ \\
& & & & $\mathrm{AAE}$ \\
\hline
\end{tabular}

Dari kurva kalibrasi asam askorbat diperoleh persamaan regresi linear dari asam askorbat yaitu $\mathrm{y}=0.0545 \mathrm{x}-0.5737$ dan $\mathrm{R}^{2}=0.998$. 
Dari hasil tiga kali pengulangan uji sampel 1000 $\mu \mathrm{g} / \mathrm{mL}$ dan diekuivalensikan dengan absorbansi dari asam askorbat sehingga didapatkan nilai 52.3798, 43.7743, dan 47.0220. Nilai-nilai yang diperoleh kemudian dirataratakan dan dihitung simpangan bakunya sehingga diperoleh nilai $47.73 \pm 4.3456 \mathrm{mg} / \mathrm{gram}$ AAE. Dari nilai ini dapat disimpulkan bahwa aktivitas antioksidan dari satu gram ekstrak etanol setara dengan $47.73 \mathrm{mg}$ asam askorbat. Jumlah ini masih cukup kecil bila dibandingkan dengan aktivitas antiradikal 2,2-difenil-1picrylhydrazyl (DPPH). Pada penelitian sebelumnya ekstrak etanol buah beringin ( $F$. Benjamina Linn.) menunjukkan aktivitas yang kuat terhadap radikal DPPH [16]. Hal ini menunjukkan bahwa ekstrak etanol buah beringin (F.Benjamina Linn.) memiliki kemampuan memerangkap radikal lebih baik dibandingkan dengan kemampuannya sebagai reduktor.

\section{Kesimpulan}

Dari hasil penentuan total kandungan antioksidan ekstrak etanol buah Beringin (Ficus benjamina Linn.) diperoleh nilai $47.73 \pm 4.3456$ mg/gram AAE.

\section{Ucapan Terima Kasih}

Terima kasih kepada Direktorat Jenderal Penguatan Riset dan Pengembangan (Ditjen Risbang) Kementerian Riset Teknologi dan Pendidikan Tinggi untuk pembiayaan penelitian ini melalui skema Penelitian Dosen Pemula.

\section{Daftar Pustaka}

1. Carocho, M.; Ferreira, I. C., A review on antioxidants, prooxidants and related controversy: natural and synthetic compounds, screening and analysis methodologies and future perspectives. Food and chemical toxicology 2013, 51, 15-25.

2. Bhattacarya, M.; Chakraborty, S., Free Radicals and Naturally Occurring Antioxidants. Journal of Pharmacognosy and Phytochemistry 2015, 3, (3).

3. Halliwell, B.; Gutteridge, J., Free radicals, other reactive species and disease. Free radicals in biology and medicine 1999, 3, 617783.
4. Tawfik, M. S.; Alhejy, M., Antioxidants in fig (Ficus carica L.) and their effects in the prevention of atherosclerosis in hamsters. $J$. Food Nutr. Sci 2014, 2, (4), 138-145.

5. Misbah, H.; Aziz, A. A.; Aminudin, N., Antidiabetic and antioxidant properties of Ficus deltoidea fruit extracts and fractions. $B M C$ complementary and alternative medicine 2013, 13, (1), 118.

6. Solomon, A.; Golubowicz, S.; Yablowicz, Z.; Grossman, S.; Bergman, M.; Gottlieb, H. E.; Altman, A.; Kerem, Z.; Flaishman, M. A., Antioxidant activities and anthocyanin content of fresh fruits of common fig (Ficus carica L.). Journal of agricultural and food chemistry 2006, 54, (20), 7717-7723.

7. Sirisha, N.; Sreenivasulu, M.; Sangeeta, K.; Chetty, C. M., Antioxidant properties of Ficus species-a review. Int J PharmTech Res 2010, 2, (4), 2174-2182.

8. Tanwar, B.; Andallu, B.; Modgil, R., Influence of processing on phytochemical characteristics and'in vitro'antioxidant actvity of'Ficus carica l'.(fig) products. International Journal of Food and Fermentation Technology 2015, 5, (2), 223.

9. Joseph, B.; Raj, S. J., Pharmacognostic and phytochemical properties of Ficus carica Linn-An overview. International journal of pharmtech research 2011, 3, (1), 8-12.

10. Çalişkan, O.; Polat, A. A., Phytochemical and antioxidant properties of selected fig (Ficus carica L.) accessions from the eastern Mediterranean region of Turkey. Scientia Horticulturae 2011, 128, (4), 473-478.

11. Harzallah, A.; Bhouri, A. M.; Amri, Z.; Soltana, H.; Hammami, M., Phytochemical content and antioxidant activity of different fruit parts juices of three figs (Ficus carica L.) varieties grown in Tunisia. Industrial Crops and Products 2016, 83, 255-267.

12. Viuda-Martos, M.; Barber, X.; Pérez-Álvarez, J. A.; Fernández-López, J., Assessment of chemical, physico-chemical, technofunctional and antioxidant properties of fig (Ficus carica L.) powder co-products. Industrial Crops and Products 2015, 69, 472479.

13. Vallejo, F.; Marín, J.; Tomás-Barberán, F. A., Phenolic compound content of fresh and dried figs (Ficus carica L.). Food Chemistry 
2012, 130, (3), 485-492.

14. Wojdyło, A.; Nowicka, P.; CarbonellBarrachina, Á. A.; Hernández, F., Phenolic compounds, antioxidant and antidiabetic activity of different cultivars of Ficus carica L. fruits. Journal of Functional Foods 2016, 25, 421-432.

15. Phatak, R. S.; Hendre, A. S., Total antioxidant capacity (TAC) of fresh leaves of Kalanchoe pinnata. Journal of Pharmacognosy and Phytochemistry 2014, 2, (5).

16. Karundeng, M.; Aloanis, A. A., Analisis Pemerangkapan radikal bebas ekstrak etanol buah beringin (Ficus benjamina Linn.). Fullerene Journal of Chemistry 2018, 3, (2), 3739. 